\title{
PENGATURAN MEREK PRODUK MAKANAN (BERDASARKANUNDANG-UNDANG NO 20 TAHUN 2016 TENTANG MEREK)
}

\author{
Oleh: \\ I Made Dwi Prasetya* \\ I Gede Putra Ariana**
Program Kekhususan Hukum Bisnis Fakultas Hukum Universitas Udayana

\begin{abstract}
ABSTRAK
Kemajuan Merek dagang di indonesia semakin banyak macam pilihannya dengan teknologi informasi dan komunikasi yang mendukung perkembangan berbagai macam-macam merek yang terkenal di masyarakat luas. Adanya kesamaan nama antara GeprekBensu milik Ruben Onsu dengan Kedai Bengkel Susu (Bensu) yang dimiliki oleh Jessy Handalim, serta terdapat permasalah sertifikat yang dimiliki oleh kedua perusahaan tersebut yang dimana keduanya memiliki kesamaan nama belakang dari merek tersebut. Maka dari itu, pemilik asli nama dari Bensu yaitu Ruben Onsu menggugat saudara Jessy Handalim ke Pangadilan Niaga atas kesamaan nama yang telah dibuat. Terdapat juga pengajuan permohonan pendaftaran produk ke Ditjen KI. Adapun tujuan yang terkandung di dalam penulisan karya ilmiah berbentuk jurnal ini yaitu untuk mengetahui bagaimana pengaturan yang mengatur mengenai merek dan upaya perlindungan hukum yang didapatkan melalui pendaftaran merek. Penulisan jurnal ini menggunakan metode penelitian hukum normatif (the statue approach) dengan pendekatan yang digunakan yaitu Peraturan Perundang-undanganserta pendekatan kasus terkait dengan merek yakni Bensu. Dengan demikian dapat disimpulkan bahwa pengaturan dasar mengenai merek produk makanan diatur dalam Undang-undang dan Peraturan Menteri Hukum dan Ham, serta upaya perlindungan yang dapat dilakukan adalah melalui pendaftaran dan melalui jalur litigasi maupun non litigasi jika terjadi sengketa dikemudian hari.
\end{abstract}

Kata Kunci:Pengaturan Hukum, Hak Merek, Produk Makanan

\begin{abstract}
Progress of Trademarks in Indonesia more and more choices with information and communication technologies that support the development of various kinds of well-known brands in the wider community. There is a similarity between Ruben Onsu's Geprek Bensu and Kedai Bengkel Susu (Bensu) owned by

Udayana.

*I Made Dwi Prasetya adalah mahasiswa Fakultas Hukum Universitas

${ }^{* *}$ I Gede Putra Ariana adalah Dosen Fakultas Hukum Universitas Udayana.
\end{abstract}


Jessy Handalim, and there are certificate problems that both companies have which both have the same last name of the brand. Therefore, the original owner of the name of Bensu, Ruben Onsu, sued Jessy Handalim to the Commercial Court for the similarity of the names he had made. There is also a request for product registration to the Directorate General of Information Technology. The purpose contained in the writing of scientific papers in the form of this journal is to find out how the arrangements governing the brand and legal protection efforts obtained through brand registration. The writing of this journal uses the normative legal research method (the statue approach) with the approach used, namely the Laws and the case approach related to the brand, Bensu. Thus it can be concluded that the basic arrangement of food product brands is regulated in the Law and Regulation of the Minister of Law and Human Rights, and safeguards that can be carried out are through registration and through litigation and non-litigation channels in the event of a dispute in the future.

Keywords:Legal Arrangement, Brand Rights, Food Products

\section{PENDAHULUAN}

\subsection{Latar Belakang}

Kemajuan Merek dagang di indonesia semakin banyak macam pilihannya dengan teknologi informasi dan komunikasi yang mendukung perkembangan berbagai macam-macam merek yang terkenal di masyarakat luas. Dengan sangat mudah dapat mencari informasi keunggulan produk dari merek terkenal yang dimiliki produk yang diinginkan oleh konsumen. Oleh karena itu, pemilik merek pada suatu produk akan bersaing untuk mendapatkan kepercayaan dari masyarakat luas. Maka dari itu diperolehlah keinginan dari konsumen yang mendorong terjadinya tindakan persaingan usaha yang tidak sehat seperti pemalsuan ataupun peniruan terhadap merek terkenal. ${ }^{1}$

Merek yang dibuat oleh pelaku usaha atau perusahaan bertujuan untuk membedakan barang atau jasa yang diproduksi. Merek dapat disebut sebagai tanda pengenal asalkan barang dan jasa yang menghubungakan tujuan dari pembuatan dari produk tersebut. Bagi konsumen merek berfungsi sebagai jaminan dari nilai hasil produksi dengan sudut pandang yang berbeda dari

\footnotetext{
${ }^{1}$ Tomi Suryo Utomo, 2010, Hak Kekayaan Intelektual di Era Global, PT Graha Ilmu, Yogyakarta, h. 28.
} 
masyarakat luas. Dengan demikian merek yang memiliki kualitas yang sangat terkenal luas oleh konsumen berpotensi untuk diikuti, ditiru, serta dibajak oleh orang-orang yang tidak bertanggung jawab. ${ }^{2}$

Undang-undang Nomor 20 Tahun 2016 menjelaskan bahwa peran dari merek yang terjadi sangatlah penting terutama untuk menjaga persaingan terhadap usaha yang baik dan sehat. Merek dapat dipakai sebagai alat untuk menjelaskan asal mula dari suatu produk, untuk mengetahui kualitas produk, serta keaslian dari suatu produk. Maka dari itu diperlukan pengaturan yang sangat memadai tentang merek yang bisa memberikan peningkatan layanan bagi masyarakat luas. ${ }^{3}$

Berdasarkan fakta berita, bahwa adanya kesamaan nama antara Geprek Bensu milik Ruben Onsu dengan Kedai Bengkel Susu (Bensu) yang dimiliki oleh Jessy Handalim, terdapat juga permasalahan sertifikat yang dimiliki oleh kedua perusahaan tersebut yang dimana keduanya memiliki kesamaan nama belakang dari merek tersebut. Pemilik asli dari nama Bensu yaitu Ruben Onsu menggugat saudara Jessy Handalim ke Pangadilan Niaga atas kesamaan nama yang telah dibuat. Oleh karena itu, terdapat pengajuan permohonan pendaftaran produk ke Ditjen Kekayaan Intelektual oleh Ruben Onsu. Akan tetapi tergugat yaitu Jessy Handalim juga sudah mendaftarkan terlebih dahulu produknya ke Ditjen Kekayaan Intelektual. Pihak dari Ruben Onsu mengajukan gugatan dengan Nomor Perkara 48/Pdt.SusHKI/Merek/2018/PN Niaga Jkt.Pst pada tanggal 25 September

\footnotetext{
${ }^{2}$ Tommy Hendra Purwaka, 2017, Perlindungan Merek, Yayasan Pustaka Obor Indonesia,Jakarta, h.7.

${ }^{3}$ OK. Sadikin, 2002, Aspek Hukum Intelektual, Raja Grafindo Persada, Jakarta, h. 329.
} 
2018. Berikut isi Gugatan yang diinginkan oleh Ruben Onsu terhadap merek Bensu:

1. Menerima dan mengabulkan Gugatan Penggugat untuk seluruhnya;

2. Menyatakan singkatan nama Penggugat "BENSU" adalah singkatan nama orang terkenal;

3. Menyatakan merek Geprek Bensu milik Penggugat adalah merek terkenal;

4. Menyatakan Penggugat sebagai pendaftar merek "BENSU" yang beritikad baik dan mempunyai hak tunggal/khusus untuk memakai merek tersebut;

5. Menyatakan merek BENSU yang didaftarkan oleh Tergugat dengan nomor IDM000622427 dalam kelas 43 dibatalkan karena merupakan singkatan nama terkenal milik penggugat;

6. Menyatakan merek BENSU yang didaftarkan oleh Tergugat dengan nomor IDM000622427 dalam kelas 43 dibatalkan karena mempunyai persamaan pada pokoknya dengan merek Geprek Bensu Penggugat;

7. Menyatakan merek BENSU yang didaftarkan oleh Tergugat dengan nomor IDM000622427 dalam kelas 43 dibatalkan karena permohonannya diajukan atas dasar iktikad tidak baik;

8. Memerintahkan turut Tergugat untuk membatalkan merek BENSU atas nama JESSY HANDALIM dengan nomor pendaftaran IDM000622427 untuk kelas 43 dengan mencoretnya dari Daftar Umum Merek dan Berita Resmi;

9. Merek dengan segala akibat hukumnya;

10. Membebankan Tergugat untuk membayar biaya perkara.

Dalam gugatan yang di buat oleh Kuasa Hukum dari Ruben Onsu sebagai pemilik utama dari nama Bensu tersebut, terdapat petitum yang dimana tergugat Jessy Handalim harus 
membatalkan pendaftaran produknya kepada Ditjen Kekayaan Intelektual yang sudah tertulis di dalam surat kuasa yang di buat oleh kuasa hukum dari Ruben Onsu yakni Minola Sebayang. Karena merek Bensu ini merupakan kepanjangan dari nama Ruben Onsu.

Oleh karena itu, permasalahan ini akan dibahas dalam karya ilmiah berbentuk jurnal yang di dalamnya membahas mengenai "Pengaturan Merek Produk Makanan (Berdasarkan UndangUndang Nomor 20 Tahun 2016 Tentang Merek)".

\subsection{Rumusan Masalah}

1. Bagaimana pengaturan dasar mengenai merek produk makanan?

2. Bagaimana upaya perlindungan hukum terhadap pendaftaran merek produk makanan?

\subsection{Tujuan Penulisan}

Adapun tujuan yang terkandung di dalam penulisan karya ilmiah berbentuk jurnal ini yaitu untuk mengetahui bagaimana pengaturan dasar mengenai merek produk makanan serta bagaimana upaya perlindungan hukum hukum terhadap pendaftaran merek produk makanan tersebut.

\section{ISI MAKALAH}

\subsection{Metode Penelitian}

Penulisan jurnal ini menggunakan metode penelitian hukum normatif (the statue approach) ${ }^{4}$ dengan pendekatan yang

${ }^{4}$ I Made Pasek Diantha, 2017, Metodologi Hukum Normatif dalam Justifikasi Teori Hukum, Prenada Media Group, Jakarta, h. 156. 
digunakan yaitu Peraturan Perundang-undangan serta pendekatan kasus yang terkait dengan merek yakni Bensu.

\subsection{Hasil dan Analisis}

\subsubsection{Pengaturan Dasar Mengenai Merek Produk Makanan}

Menurut ketentuan Undang-undang Nomor 20 Tahun 2016 TentangMerek dan Indikasi Geografis, pengertian dari Merek terdapat dalam Pasal 1 ayat (1) yang menentukan bahwa merek adalah tanda yang dapat ditampilkan secara grafis berupa gambar, logo, nama, susunan angka,susunan warna, dalam bentuk dua dimensi atau tiga dimensi, suara, hologram, atau kombinasi dari dua atau lebih dari unsur tersebut untuk membedakan barang dan/atau jasa yang diproduksi olehorang atau badan hukum dalam kegiatan perdagangan barang atau jasa. Merek adalah salah satu aset yang sangat berharga bagi setiap perusahaan. Dengan merek yang diseleksi dan dipelihara secara baik bagi perusahaan yang dapat menjalankan dan mengembangkan bisnis dalam melindungi konsumen yang ada diperusahaan tersebut. 5

Sejak zaman kuno periode Minoan misalnya, orang sudah memberikan tanda untuk barang-barang miliknya, hewan, dan bahkan manusia. Di Era yang sama bangsa Mesir sudah memahat namanya untuk batu bata yang dibuat atas perintah Raja. Perundang-undangan tentang merek dimulai dari Statute of Parma yang dimana merek difungsikan sebagai pembeda untuk produk seperti pisau, pedang, maupun barang yang terbuat dari tembaga lainnya. ${ }^{6}$

Penggunaan merek dagang yang kita kenal sekarang ini mulai dikenal tidak lama setelah Revolusi Industri pada

${ }^{5}$ OK. Sadikin, Opcit, h. 154.

${ }^{6}$ Rahmi Jened, 2007, Hak Kekayaan Intelektual Penyalahgunaan Hak Eksklusif, Airlangga University Press, Surabaya, h. 159. 
pertengahan abad XVIII. Yang dimana pada saat itu sistem produksi yang berasal dari abad pertengahan lebih mengutamakan keterampilan kerja tangan, akan tetapi berubah drastis sebagai akibat digunakannya mesin-mesin dengan kapasitas produksi yang tinggi.

Bersamaan dengan berkembangnya industri, berkembang pula penggunaan iklan untuk memperkenalkan produk. Sejalan dengan berkembang dan meningkatnya penggunaan iklan, maka meningkat pula penggunaan merek dalam fungsi yang modern yaitu sebagai tanda pengenal akan asal atau sumber produsen dari barang-barang yang bersangkutan. ${ }^{7}$ Pada masa itu, telah dikenal penggunaan merek perniagaan (marques de commerce, trademark, merk) dalam pengertian sendiri sebagai tandingan merek perusahaan (marques de fabrique, manufacturer's mark, fabrieksmereken).

Dari sejarah perkembangannya, diketahui bahwa hukum merek yang berkembang pada pertengahan abad XIX, sebagai bagian dari hukum yang mengatur masalah persaingan curang dan pemalsuan barang. Norma dasar perlindungan merek bahwa tidak ada seorang pun yang berhak menawarkan barangnya kepada masyarakat seolah-olah sebagai barang pengusaha lainnya yaitu dengan menggunakan merek yang sama yang dikenal oleh masyarakat sebagai merek dari pengusaha lainnya. Lambat laun perlindungan diberikan sebagai suatu pengakuan bahwa merek tersebut sebagai milik dari orang yang telah memakainya sebagai tanda pengenal dari barang-barangnya dan untuk membedakanya dari barang-barang lain yang tidak menggunakan merek tersebut. Pengakuan tersebut didasarkan pada pengetahuan dari masyarakat bahwa merek dagang itu berfungsi sebagai daya

${ }^{7}$ Rahmi Jened, 2015, Hukum Merek Trademark Law dalam Era Global \& Integrasi Ekonomi, PT Kharisma Putra Utama, Jakarta, h. 2. 
pembeda. Pengenalan tersebut mendorong masyarakat untuk membeli barang yang memakai merek tertentu tersebut, sehingga menjadikannya sebagai objek hak milik dari pemilik dari merek yang bersangkutan. 8

Adapun pengaturan dasar mengenai merek yaitu sebagai berikut:

1. Undang-undang Nomor 20 Tahun 2016 Tentang Merek dan Indikasi GeografisTambahan Lembaran Negara Republik Indonesia Nomor 5953;

2. Peraturan Menteri Hukum dan HAM Republik Indonesia No. 67 Tahun 2016 Tentang Pendaftaran Merek.

Jadi, berdasarkan kasus antara Geprek Bensu milik Ruben Onsu dengan Kedai Bengkel Susu (Bensu) milik Jessy Handalim, apabila Ruben Onsu yang pertama kali mendaftarkan mereknya dibanding Jessy Handalim, maka Ruben lah yang berhak mendapat perlindungan hukum serta berhak atas sertifikat merek Bensu dengan merujuk ketentuan yang mengatur mengenai merek diatas. Apabila ada pihak lain yang ingin menggunakan merek Bensu tersebut, maka harus meminta izin terlebih dahulu oleh pemilik aslinya yaitu Ruben Onsu.

\subsubsection{Upaya Perlindungan Hukum Terhadap Pendaftaran Merek Produk Makanan}

Perlindungan hukum adalah segala upaya pemenuhan serta pemberian bantuan untuk memberikan kesan aman kepada saksi atau korban. Perlindungan hukum sebagai korban kejahatan merupakan bagian dari perlindungan masyarakat dan dapat diwujudkan dalam berbagai bentuk seperti pemberian kompensasi, pelayanan medis, dan bantuan hukum. Philipus M.

\footnotetext{
${ }^{8}$ Ibid, h. 4.
} 
Hadjon berpendapat bahwa perlindungan hukum adalah kumpulan peraturan-peraturan atau kaidah yang akan dapat melindungi suatu hal dari hal lainnya. Apabila berkaitan dengan konsumen, berarti hukum memberikan perlindungan terhadap hak-hak pelanggan dari sesuatu yang mengakibatkan tidak terpenuhinya hak-hak tersebut. ${ }^{9}$

Maka dari itu dalam permasalahan nama merek antara Geprek Bensu milik Ruben Onsu dengan Kedai Bengkel Susu (Bensu) yang dimiliki oleh Jessy Handalim upaya yang dapat dilakukan untuk memperoleh perlindungan hukum apabila merek tersebut belum terdaftar atau didaftarkan yaitu dengan melalui pendaftaran merek yang terdapat dalam Undang-undang Nomor 20 Tahun 2016 Tentang Merek dan Indikasi Geografis Pasal 4 hingga 8. Pasal 4 Undang-undang No 20 Tahun 2016 menetapkan syarat dan tata cara pendaftaran merek :

(1) Permohonan pendaftaran merek diajukan oleh Pemohon atau Kuasanya Kepada Menteri secara elektronik atau nonelektronik;

(2) Dalam Permohonan sebagaimana dimaksud pada ayat (1) harus mencantumkan:

a. Tanggal, bulan, dan tahun Permohonan;

b. Nama lengkap, kewarganegaraan, dan alamat pemohon;

c. Nama lengkap dan alamat kuasa jika permohonan diajukan melalui kuasa;

d. Warna jika merek yang dimohonkan pendaftarannya menggunakan unsur warna;

e. Nama Negara dan tanggal permintaan merek yang pertama kali dalam hal permohonan diajukan dengan hak prioritas; dan

\footnotetext{
${ }^{9}$ Tommy Hendra Purwaka, Opcit, h.15.
} 
f. Kelas barang dan/atau kelas jasa serta uraian jenis barang dan/atau jenis jasa

(3) Permohonan ditandatangani Pemohon atau Kuasanya;

(4) Permohonan sebagaimana dimaksud pada ayat (1) dilampiri dengan label Merek dan bukti pembayaran biaya;

(5) Biaya permohonan pendaftaran merek ditentukan per kelas barang dan/atau jasa;

(6) Dalam hal merek sebagaimana dimaksud pada ayat (4) berupa bentuk 3 (tiga) dimensi, label merek yang dilampirkan dalam bentuk karakteristik dari merek tersebut;

(7) Dalam hal merek sebagaimana dimaksud pada ayat (4) berupa suara, label merek yang dilampirkan berupa notasi dan rekaman suara;

(8) Permohonan sebagaimana dimaksud pada ayat (1) wajib dilampiri dengan surat pernyataan kepemilikan merek yang dimohonkan pendaftarannya;

(9) Ketentuan lebih lanjut mengenai biaya permohonan sebagaimana dimaksud pada ayat (5) diatur dengan Peraturan Pemerintah.

Disamping itu dalam ketentuan Pasal 5 menetapkan bahwa dalam hal permohonan diajukan oleh lebih dari satu pemohon yang secara bersama-sama berhak atas merek tersebut, semua nama pemohon dicantumkan dengan memilih salah satu alamat sebagai alamat pemohon. Permohonan tersebut ditandatangani oleh salah satu dari pemohon yang berhak atas merek tersebut dengan melampirkan persetujuan tertulis dari para pemohon yang mewakilkan. Permohonan yang salah seorang pemohonnya atau lebih warga Negara asing dan badan hukum asing yang berdomisili diluar negeri wajib diajukan melalui kuasa. Permohonan tersebut 
diajukan melalui kuasanya, surat kuasa untuk itu ditandatangani oleh semua pihak yang berhak atas merek tersebut.

Selanjutnya Pasal 6 menetapkan bahwa permohonan untuk lebih dari 1 (satu) kelas barang dan/atau jasa dapat diajukan dalam satu permohonan. Permohonan tersebut harus menyebutkan jenis barang dan/atau jasa yang termasuk dalam kelas yang dimohonkan pendaftarannya. Ketentuan mengenai kelas barang dan/atau jasa diatur lebih lanjut dengan Peraturan Menteri.

Kemudian Pasal 7 menetapkan bahwa permohonan dan hal yang berkaitan dengan administrasi merek yang diajukan oleh pemohon yang bertempat tinggal atau berkedudukan tetap diluar wilayah NKRI wajib diajukan melalui kuasa. Dan pemohon tersebut wajib menyatakan dan memilih alamat kuasa sebagai domisili hukum di Indonesia.

Serta berdasarkan ketentuan Pasal 8 menetapkan bahwa ketentuan mengenai syarat dan tata cara permohonan diatur lebih lanjut dengan Peraturan Menteri.

Indonesia menganut asas first to file system yang berarti perlindungan hukum dari suatu merek hanya akan diberikan kepada pihak yang pertama kali mengajukan permintaan pendaftaran untuk suatu merek, dan Negara tidak memberikan pendaftaran untuk merek yang memiliki persamaan dengan merek yang diajukan lebih dahulu tersebut untuk barang atau jasa sejenis. Dengan telah didaftarkannya merek tersebut, maka yang pertama kali mendaftarkan mereknya sudah mendapatkan perlindungan hukum yang tetap.

Apabila ada pihak yang mencoba menggunakan merek yang sudah terdaftar tersebut tanpa izin dari pemilik aslinya dapat menimbulkan akibat hukum yaitu berupa sanksi pidana yang 
sebagaimana diatur dalam Pasal 100 ayat (2) Undang-undang Nomor 20 Tahun 2016 yang menentukan bahwa "Setiap orang yang dengan tanpa hak menggunakan Merek yang mempunyai persamaan pada pokoknya dengan Merek terdaftar milik pihak lain untuk barang dan/atau jasa sejenis yang diproduksi dan/atau diperdagangkan, dipidana dengan pidana penjara paling lama 4 (empat) tahun dan/atau denda paling banyak Rp2.000.000.000,00 (dua miliar rupiah). Disamping itu bagi pihak yang menimbulkan kerugian kepada pemilik asli dari merek yang bersangkutan dapat mengajukan gugatan secara perdata melalui jalur litigasi berdasarkan ketentuan Pasal 1365 KUH Perdata kepada pengadilan yang berwenang, serta melalui jalur non litigasi.

\section{PENUTUP}

\subsection{Kesimpulan}

Perlindungan hukum terhadap pendaftaran merek produk makanan berdasarkan ketentuan Pasal 4 hingga Pasal 8 Undangundang Nomor 20 Tahun 2016 bahwa pendaftar pertama berdasarkan asas first to file system yang artinya bahwa pendaftar pertama lah yang berhak untuk menggunakan secara sah merek tersebut. Berkaitan dengan kasus Ruben Onsu dalam hal Ruben yang pertama kali mendaftarkan merek bensunya, maka Ruben lah yang berhak mendapatkan perlindungan hukum serta menggunakan sertifikat merek Bensu tersebut.

Apabila pihak lain yang ingin menggunakan atau mencoba memakai merek tersebut tanpa izin dari pemilik aslinya maka terdapat sanksi Pidana yang terdapat dalam Pasal 100 ayat (2) Undang-undang Nomor 20 Tahun 2016 serta sanksi 
perdatamelalui jalur litigasi sebagaimana dimaksud dalam ketentuan Pasal 1365 KUH Perdata, maupun jalur non litigasi.

\subsection{Saran}

Sebaiknya kepada pemilik asli dari merek Bensu yaitu Ruben Onsu mengajukan permohonan pendaftaran merek kepada Ditjen Kekayaan Intelektual sesuai dengan prosedur yang telah ditentukan, agar kedepannya tidak terjadi permasalahan dalam penggunaan merek yang bersangkutan.

\section{DAFTAR PUSTAKA}

\section{BUKU}

Jened, Rahmi, 2007, Hak Kekayaan Intelektual Penyalahgunaan Hak Eksklusif, Airlangga University Press, Surabaya.

, 2015, Hukum Merek Trademark Law dalam Era Global \& Integrasi Ekonomi, PT Kharisma Putra Utama, Jakarta.

Pasek Diantha, I Made, 2017, Metodologi Hukum Normatif dalam Justifikasi Teori Hukum, Prenada Media Group, Jakarta.

Purwaka, Hendra Tommy, 2017, Perlindungan Merek, Yayasan Pustaka Obor Indonesia, Jakarta.

Sadikin, OK., 2002, Aspek Hukum Hak Kekayaan Intelektual Intellectual Property Right, Rajagrafindo Persada, Jakarta.

Suryo Utomo, Tomi, 2010, Hak Kekayaan Intelektual di Era Global, PT Graha Ilmu, Yogyakarta.

\section{ARTIKEL}

Alif Khoironi,Iffan, 2013,"Implementasi Pendaftaran Merek Sebagai Bentuk Perlindungan Hukum Pada Home Industry Eggroll", Jurnal Hukum UNNES, Vol.II, No. 2, Agustus-Oktober

Dwi Putra,Fajar Nurcahya, 2014,"Perlindungan Hukum Bagi Pemegang Hak Atas Merek Terhadap Perbuatan Pelanggaran Merek", Jurnal Ilmu Hukum, Vol. III, No. 3, Januari-Juni 
Marwiyah Siti, 2010, "Perlindungan Hukum Atas Merek Terkenal", Jurnal Syariah dan Hukum, Vol. II, No. 1, Juni

\section{PERATURAN PERUNDANG-UNDANGAN}

Kitab Undang-undang Hukum Perdata

Undang-undang Nomor 20 Tahun 2016 Tentang Merek dan Indikasi Geografis Tambahan Lembaran Negara Republik Indonesia Nomor 5953.

Peraturan Menteri Hukum dan HAM Republik Indonesia Nomor 67 Tahun 2016 Tentang Pendaftaran Merek. 